\title{
1 Influence of Saharan dust on Atlantic tropical cyclones
}

\author{
Zhenxi Zhang ${ }^{1}$ and Wen Zhou ${ }^{2}$
}

$3 \quad{ }^{1}$ College of Energy and Power Engineering, Inner Mongolia University of Technology, Hohhot

4 010010, China. Email: xizhenz690400.student@sina.com

$5{ }^{2}$ School of Energy and Environment, City University of Hong Kong, Hong Kong, Tat Chee

6 Avenue, Kowloon, Hong Kong 999077, China. Email: wenzhou@cityu.edu.hk

7 Correspondence to: Zhenxi ZHANG (xizhenz690400.student@sina.com)

\section{Abstract}

9 The influence of Saharan dust outbreaks on summertime Atlantic tropical cyclone (TC)

10 activity is explored using continuous atmospheric reanalysis products and TC track

11 data from 1980 to 2019. Analyses reveal that the Saharan dust plume over the tropical

12 Atlantic can affect TC activity by affecting the atmospheric hydrology and radiation

13 absorbed by the earth's surface, which can be classified into three mechanisms. (1) A

14 strong Saharan dust plume indirectly induces the reduction of atmospheric moisture,

15 which further suppresses TC track, number of TC days, and intensity, with the influence covering the whole tropical Atlantic. (2) A strong Saharan dust plume enhances atmospheric moisture just along the North Atlantic ITCZ through the dust microphysical effect, which further promotes TC activity along $10^{\circ} \mathrm{N}$ latitude in June. (3) The climatological influence of dust on TC activity is caused by the strong radiative forcing of Saharan dust over the eastern tropical Atlantic in June, which produces an evident reduction in SST and lessens the duration and intensity of regional TC activity in June, according to the 40-yr average from 1980 to 2019. 


\section{Introduction}

Atlantic tropical cyclones (TCs) are becoming more destructive economically, as evidenced by the fact that five of the ten most expensive storms in United States history have occurred since 1990. According to the World Meteorological Organization, the societal impact TCs has recently increased for the rising populations and infrastructure in coastal regions.

When easterly trade winds pass over the Saharan Desert, dust and dry air mix to form a layer called the Saharan air layer (SAL), which extends westward from West Africa to the North Atlantic, with easterly trade winds in the tropics, and occurs over extensive portions of the northern tropical Atlantic Ocean. Observational analysis and numerical simulation have suggested that the formation and intensity of TCs in the Atlantic are influenced by the SAL (Dunion and Velden, 2004; Wu et al., 2006; Evan et al., 2006). The SAL prevents TCs from intensifying into mature hurricanes because they are highly negatively correlated with each other. Wu (2007) further investigated the role played by the SAL in long-term changes in TC intensity. Dunion and Velden (2004) attributed the interaction between TCs and the SAL to fluid dynamical mechanisms, e.g., vertical wind shear and suppression of deep convection caused by the SAL. However, less attention has been paid to the relationship between TC activity and the impact of dust on the atmospheric hydrology and radiation absorbed by the earth's surface.

The SAL transports large plumes of Saharan dust across the northern tropical Atlantic. As absorbing aerosols, mineral dust absorbs solar radiation to heat the atmosphere and enhance cloud evaporation, known as the semi-direct effect (Huang et al., 2006; Lau et al., 2009). In microphysics, mineral dust particles are effective cloud condensation nuclei (Koehler et al., 2009; Karydis et al., 2011) and ice nuclei (Chen et al., 1998; Hoose and Mohler, 2012; Cziczo et al., 2013). Saharan dust, especially, has been found to enhance ice cloud during its transport across the Atlantic (DeMott et al., 2003; Sassen, 2003; Cziczo et al., 2004). Aerosols can absorb and scatter solar 
radiation, leading to a large reduction in the solar radiation absorbed by the earth's surface, which is referred to as direct radiative forcing (Ramanathan et al., 2001). Through direct radiative forcing, dust particles can cool the surface (Cavazos et al., 2009). Numerical experiments on a Saharan dust storm suggest that strong radiative forcing of dust particles can reduce surface temperature by $0.2-0.5 \mathrm{~K}$ over most of western Europe (Bangert et al., 2012).

The objective of this study is to investigate the relationship between Atlantic TC activity and the changes in atmospheric hydrology and surface temperature caused by Saharan dust. Data are described in section 2. The impacts of Saharan dust on the atmospheric hydrology and sea surface temperature (SST) over the tropical Atlantic are discussed in sections 3 and 4, respectively. The influence of Saharan dust on Atlantic TC activity is analyzed in section 5. A summary and conclusions are presented in section 6 .

\section{Datasets}

The Modern-Era Retrospective Analysis for Research and Applications (MERRA) is a satellite-era atmospheric reanalysis (Rienecker et al., 2008) that focuses on analyses of the global hydrological cycle regarding precipitation and water vapor climatology (Rienecker et al., 2011). The new version of MERRA, MERRA-2, improves the computation of the hydrological cycle (Takacs et al., 2015; Reichle and Liu, 2014) by not only incorporating new observations but also reducing spurious trends and jumps caused by changes in meteorological observations (McCarty et al., 2016).

It is significant that MERRA-2 includes analyzed aerosol fields for the first time, to allow the investigation of aerosol-climate or aerosol-weather interactions (Bellouin et al., 2013; Reale et al., 2014). Aerosol simulation in MERRA-2 is implemented with a radiatively coupled version of the Goddard Chemistry, Aerosol, Radiation, and Transport model (GOCART, Chin et al., 2002; Colarco et al., 2010). The Aerosol Optical Depth (AOD) and other observable aerosol properties simulated with the GOCART aerosol module have been validated by numerous studies (e.g., Colarco et 

Imaging SpectroRadiometer (MISR) (Kahn et al., 2005), as well as ground-based measurements of AOD from the AErosol Robotic NETwork (AERONET) (Holben et al., 1998). The MERRA-2 data used in this study are the monthly dust AOD, liquid water path (LWP), ice water path (IWP), and sea surface temperature (SST) for 1980-2019, with a resolution of $0.625^{\circ}$ longitude by $0.5^{\circ}$ latitude. LWP and IWP are the vertical integration of the liquid and ice water in the air column, respectively.

Atlantic TC track data for 1980-2018 are obtained from NOAA's Tropical Prediction Center. TC data in 2019 are obtained from the National Hurricane Center (NHC) Hurricane Best Track Files. All the data are recorded at six-hour intervals, and missing data are indicated by zeros. The parameters contained in the data include the month, day of the month, hour (GMT), latitude (degrees), longitude (0-360 degrees), maximum wind speed $\left(\mathrm{m} \mathrm{s}^{-1}\right)$, and central surface pressure $(\mathrm{hPa})$.

\section{Association patterns of LWP and IWP with dust}

In this section, we discuss the impact of Saharan dust on LWP and IWP over the Atlantic through the semi-direct and microphysical effects. The observed dust AOD over the North Atlantic peaks in the summer (Kaufman et al., 2005), while the Atlantic hurricane season occurs mainly in summer. Figure 1 is the $40-\mathrm{yr}$ averaged (1980-2019) monthly dust extinction AOD from June to September, which presents the monthly variation in the transport of large plumes of Saharan dust across the northern tropical Atlantic.

\subsection{LWP}

Figure 2 shows the 40-yr (1980-2019) average of LWP during the summer. Climatologically, LWP occurs over the Atlantic ITCZ and the western and central tropical Atlantic, with the maximum appearing along the ITCZ between $20^{\circ} \mathrm{W}$ and 
$50^{\circ} \mathrm{W}$, which shows a descending tendency in intensity and area from June to September. An absence of LWP occurs over the eastern tropical Atlantic, collocated with regions of heavy dust loading, and the region of LWP absence migrates eastward and northward from June to September, corresponding to the monthly variation in the westward extension of the Saharan dust plume.

To study the long-term statistical relationship between dust AOD and LWP, inter-annual correlation is computed between the monthly averaged dust AOD and LWP at each grid point during 1980-2019, which is also shown in Figure 2. This analysis reveals that LWP has significant negative correlations with dust AOD in two parts of the tropical Atlantic. One is in the Caribbean Sea and appears in June. Another is in the eastern tropical Atlantic where the gradient of LWP is very large, as can be seen in August and September. Marine areas with a significant negative correlation $(<-0.5)$ are larger in August than in other months.

Although correlation computations present the negative response of LWP to dust AOD, this is a qualitative result. And this response does not indicate a complete linear relationship according to the value of the correlation coefficient. On the other hand, the impact of strong dust storms is significantly underestimated by the climatology of the dust plume (Figure 1), which represents just the background levels. Therefore, 8 years with the strongest and weakest dust AOD (averaged over the region of $10^{\circ} \mathrm{N}-25^{\circ} \mathrm{N}, 60^{\circ} \mathrm{W}-20^{\circ} \mathrm{W}$ ) are selected during $1980-2019$ to construct the strongest and weakest dust conditions, respectively. Table 1 gives the magnitude of change in the strongest and weakest dust AOD compared to climatology.

The magnitude of the changes in LWP in the 8-yr strongest and weakest dust conditions is shown in Figure 3. The LWP difference map of strong-minus-mean shows that the strengthening Saharan dust plume continuously suppresses LWP from June to September, with the most pronounced suppression of $0.025-0.075 \mathrm{~kg} \mathrm{~m}^{-2}$ appearing at several locations of the dust plume zone over the eastern tropical Atlantic. These locations are basically the same as the response regions shown by the grid point correlation computation (Figure 2). The regions with reduced LWP migrate eastward 
from the Caribbean Sea in June to offshore of the continent in September, corresponding to the monthly variation in the westward extension of the dust plume. September has the largest response region of LWP of any month to the strengthening dust plume, with a zonal range from $5^{\circ} \mathrm{N}$ to $35^{\circ} \mathrm{N}$. On the other hand, LWP is enhanced when the Saharan dust plume becomes weak, as shown by the LWP difference of weak-minus-mean. The magnitude of the increase is greatest in July, in the range of $0.05-0.15 \mathrm{~kg} \mathrm{~m}^{-2}$. The response of LWP in September is weak because the region with enhanced LWP is very scarce and small. The negative response of LWP to dust AOD is indicated not only qualitatively by correlation computations, but also quantitatively in the extreme dust conditions. Apparently, this feature is robust because it is independent of the analysis method and data sample. The analysis in Figures 2 and 3 reveals the details of the semi-direct effect of Saharan dust on LWP over the Atlantic, including temporal variation, spatial distribution, and magnitude of change.

The warm and dry air masses in the SAL originate from the west coast of Africa and extend westward to the tropical Atlantic. The mixture of these warm and dry air masses with cool and wet marine air masses can reduce the humidity of the atmosphere, inducing an absence of LWP over the eastern tropical Atlantic (Figure 2). However, the reduction of LWP shown in Figure 3 occurs with strong dust conditions and is located over the western tropical Atlantic, coinciding with the top of the dust plume tongue. This demonstrates that the reduction of LWP shown in Figure 3 is associated with the dust semi-direct effect, not the warm and dry air masses in the SAL.

\subsection{IWP}

Figure 4 shows the climatology pattern of IWP. Compared to the LWP pattern (Figure 
variation of LWP, the region of absence of IWP over the eastern tropical Atlantic migrates eastward and northward from June to September. Figure 4 also displays the correlation between dust AOD and IWP at each grid point. IWP in the southern Caribbean has significant negative correlations with dust AOD in June, the same as the LWP pattern (Figure 2). IWP over the African Sahel and adjacent offshore region consistently shows negative correlations with dust AOD from June to September, and this association of IWP with dust AOD becomes strongest in August because of the strongest negative correlation coefficient $(<-0.7)$ and largest impact area.

Figure 5 shows the difference in IWP between the extreme dust conditions and 40-yr average, which is analyzed according to the dust semi-direct effect firstly. In June, the IWP difference between the 8-yr strongest dust conditions and the 40-yr average shows that the intensification of the dust plume is accompanied by a reduction of IWP in the region of the dust plume tongue over the western Atlantic, with the magnitude of change in IWP being $0.05-0.15 \mathrm{~kg} \mathrm{~m}^{-2}$. A weakened dust plume cannot affect the same region where IWP is almost the same as the 40-yr average, without obvious change, as shown by the IWP difference between the 8-yr weakest dust conditions and the 40-yr average. In the strongest dust conditions in August and September, there is a reduction of $0.05-0.15 \mathrm{~kg} \mathrm{~m}^{-2}$ in IWP over the African Sahel and adjacent offshore region compared to the $40-\mathrm{yr}$ average. In contrast, IWP increases by $0.05-0.1 \mathrm{~kg} \mathrm{~m}^{-2}$ in the weakest dust conditions, but this enhancement appears only in very small areas offshore of the African Sahel. Besides showing the magnitude of the change in IWP, Figure 5 indicates that the features presented above are consistent with the results of the linear correlation analysis (Figure 4).

Besides the semi-direct effect, the difference in IWP shown in Figure 5 is also analyzed according to the dust microphysical effect. In June and July, directly south of the dust plume, IWP along the North Atlantic ITCZ is enhanced by $0.05-0.3 \mathrm{~kg} \mathrm{~m}^{-2}$ (0.05-0.25 $\mathrm{kg} \mathrm{m}^{-2}$ in June; $0.05-0.3 \mathrm{~kg} \mathrm{~m}^{-2}$ in July) in the strongest dust condition and reduced by $0.05-0.15 \mathrm{~kg} \mathrm{~m}^{-2}$ in the weakest dust condition. The positive relationship of IWP with dust in July even appears in northern South America. This response of 
IWP to dust is similar to observations (Wilcox et al., 2010) and simulations (Lau et al., 2009) of enhanced summer precipitation along the ITCZ during dust outbreaks.

A comparison between Figures 3 and 5 shows that the response area of LWP to dust is evidently larger than that of IWP, indicating a stronger dust semi-direct effect on LWP than on IWP. Attributed to dust radiative heating (Carlson and Benjamin, 1980; Alpert et al., 1998; Zhu et al., 2007; Wong et al., 2009), the transport of the Saharan dust plume is accompanied by significant warming between 900 and $600 \mathrm{hPa}$ (Wilcox et al., 2010), and its impact on liquid water cloud in the lower troposphere is larger than on ice cloud in the upper troposphere.

\section{Association patterns of SST with dust}

Figure 6 shows the climatology of SST over the tropical Atlantic. Besides the northward decrease from the ITCZ, the most pronounced feature of SST distribution is the eastward decrease, with the maximum in the Gulf of Mexico and Caribbean Sea, and the minimum offshore of Africa. This zonal variation of SST indicates an eastward migration tendency from June to September. A grid point correlation between SST and dust AOD is also presented in Figure 6. Because only the strong radiative forcing of dust is associated with a reduction in surface temperature (Bangert et al., 2012), the correlation coefficients are computed over the dust plume regions where dust AOD is larger than 0.15. SST consistently shows negative correlations with dust AOD from June to September, with the largest response area in June. Although the association of SST with dust AOD is the same as for LWP and IWP, the degree of the negative correlation (coefficient can be -0.5 ) is smaller than for LWP and IWP (coefficient can be -0.7).

Figure 7 shows the difference in SST between the extreme dust conditions and the 40-yr average. It is in June and September that SST presents an evident response to dust AOD. Over the dust plume regions, there is a general reduction in SST under the strong dust condition compared to the 40-yr average, and an increase in SST under the weak dust condition (the increase in June is not shown, because its magnitude is 
smaller than $0.2{ }^{\circ} \mathrm{C}$ ). The most pronounced response of SST to dust appears in June, because the reduction in SST in June $\left(0.2-0.6{ }^{\circ} \mathrm{C}\right)$ is twice the magnitude of that in September $\left(0.1-0.3^{\circ} \mathrm{C}\right)$. The analyses in Figures 6 and 7 reveal the impact of dust on SST through direct radiative forcing, including temporal variation and spatial distribution. Table 2 lists the magnitude of change in SST averaged over the region of $10^{\circ} \mathrm{N}-25^{\circ} \mathrm{N}, 60^{\circ} \mathrm{W}-20^{\circ} \mathrm{W}$, corresponding to the strong and weak dust conditions, respectively. In June, the reduction of SST related to strong dust radiative forcing accounts for $1.22 \%$ of the $40-y r$ average, which is larger than that in any other month.

\section{Association patterns of TCs with dust}

Atlantic TC statistics are obtained by summing the total number of TC days (and intensity) in a 4-degree grid cell. Figures 8 and 9 show the regions with TC days and intensity statistics in the strong and weak dust conditions. A comparison of TC statistics between the strong and weak dust conditions reveals that the strengthening Saharan dust plume can suppress TC duration and intensity. In detail, this suppression in the strong dust condition can be reflected in two aspects. The first is the variability of the region with the TC track. In June, TC tracks are mostly on the western flanks of the tropical Atlantic and mostly along the shoreline. In July, less TC activity occurs in the dust plume region. The second aspect of the suppression is the variability of the magnitude of TC days and intensity. In August and September, there is an evident decrease in TC days and intensity in the dust plume region. The monthly variation in the longitudinal location of the suppression regions presents an eastward migration from the Gulf of Mexico in June to the eastern tropical Atlantic in September, which coincides with the response of LWP to the dust semi-direct effect. The monthly variation of this suppression from June to September presents a weakness, which is consistent with the weakness in the monthly variation of the westward extension of the Saharan dust plume.

According to the steady state theory of TCs, a radially and vertically directed overturning circulation known as the Carnot cycle governs the energy of a TC 
251 (Emanuel, 1986; Rotunno and Emanuel, 1987) and provides an upper bound on the maximum wind speed in a TC (Emanuel, 1995). In the Carnot cycle, air with abundant moisture flows into a TC in the boundary layer (Emanuel, 1986). With the rising motion in a TC, the warm moist air moves upward and cools to saturation as the temperature decreases. By condensing moisture into cloud and precipitation, the Carnot cycle converts latent heat to sensible heat to provide the energy of a TC (Emanuel, 1999). Therefore, the maintenance of a TC apparently depends on the condensation of moisture into cloud. The Saharan dust plume resides in a thick layer above the marine boundary layer (Karyampudi and Carlson, 1988). Its semi-direct effect on LWP can reduce the condensation of moisture into cloud, which suppresses the maintenance of TC activity. One notable aspect of the strong dust condition in June is the appearance of TC activity along $10^{\circ} \mathrm{N}$ latitude over the eastern tropical Atlantic, which is consistent with the response of IWP to the dust microphysical effect (Figure 5). This demonstrates that Saharan dust can promote TC activity by enhancing IWP through the microphysical effect. However, this effect is minor in its intensity and area of influence, compared to the semi-direct effect.

Figure 10 shows the monthly variation in SST, IWP, TC days (on a logarithmic scale), and TC intensity (on a logarithmic scale) over the region of $20^{\circ} \mathrm{W}-60^{\circ} \mathrm{W}, 10^{\circ} \mathrm{N}-30^{\circ} \mathrm{N}$. The results indicate the climatology because they are averaged over the 40 -yr period (1980-2019). The monthly variations in both SST and IWP present a linear increase from June to September. The monthly variations in TC days and intensity (on a logarithmic scale) present the same linear increase as SST but from July to September, while the results in June are too small to satisfy this linear relationship. According to the maximum potential intensity theory (Emanuel, 1987; Holland, 1997), a TC will be strengthened if SST increases, which has been shown by numerical simulations applying environmental thermodynamic conditions based on global warming experiments (Knutson et al., 1998). Therefore, it is the pronounced reduction of SST 


\section{Summary and conclusions}

While the impact of Saharan dust on the atmospheric hydrology and radiation absorbed by the earth's surface has been documented in previous studies, less academic attention has been paid to the influence of the Saharan dust plume on Atlantic TC activity.

In this study, evidence is provided through statistical analyses of various datasets associated with the Saharan dust plume, atmospheric hydrology, surface temperature, and Atlantic TC activity over the past 40 years, suggesting that the Saharan dust plume over the tropical Atlantic can affect TC activity by impacting the atmospheric hydrology and radiation absorbed by the earth's surface. The influence of the Saharan dust plume on Atlantic TC activity is complex, and its mechanism and related spatial and temporal characteristics are summarized as below.

(1) The strong radiative forcing of Saharan dust over the eastern tropical Atlantic in June is found to produce a pronounced reduction of SST, in the range of $0.2-0.6{ }^{\circ} \mathrm{C}$. This response of SST to dust radiative forcing helps explain why the duration and intensity of regional TC activity in June is very small, compared to the increase in TC activity during the hurricane season (July to September). This mechanism for the influence of dust on TC activity is climatological in scale because the weakness of TCs is presented in the 40-yr average from 1980 to 2019, but is evident only in June.

(2) The strengthening Saharan dust plume over the tropical Atlantic during summer induces the reduction of LWP and IWP through the dust semi-direct effect, which further suppresses TC activity because the energy of a TC comes from the condensation of moisture during the Carnot cycle. This suppression of TC activity is present in the variability of the region with the TC track (mainly in June and July) and in the variability of the magnitude of TC days and intensity (mainly in August and September). Both of these show an eastward migration, coinciding with the weakness in the monthly variation of the westward extension of the Saharan dust plume. This 
mechanism for the influence of dust on TC activity occurs when Saharan dust is intensified and is implemented mainly through LWP because of the stronger dust semi-direct effect on LWP than on IWP, with the influence covering the whole Atlantic from the Gulf of Mexico in June to the eastern tropical Atlantic in September. (3) The strengthening Saharan dust plume is found to enhance IWP along the North Atlantic ITCZ through the dust microphysical effect, which further promotes TC activity along $10^{\circ} \mathrm{N}$ latitude over the eastern tropical Atlantic in June, by providing more energy to TCs from moisture condensation. Differentiated from the influence of dust on TC activity induced by radiative forcing and the semi-direct effect, this influence of dust on TC activity induced by the microphysical effect is positive, but it is also minor because it occurs only along the ITCZ over the eastern tropical Atlantic in June.

Data availability.

The MERA-2 monthly dust AOD dataset is available at https://goldsmr4.gesdisc.eosdis.nasa.gov/data/MERRA2_MONTHLY/M2TMNXAER. 5.12.4/. The MERRA-2 monthly LWP and IWP datasets are available at https://goldsmr4.gesdisc.eosdis.nasa.gov/data/MERRA2_MONTHLY/M2TMNXCSP. 5.12.4/. The MERRA-2 monthly SST dataset is available at https://goldsmr4.gesdisc.eosdis.nasa.gov/data/MERRA2_MONTHLY/M2TMNXOC N.5.12.4/. Atlantic TC track data in 2019 is available at https://www.nhc.noaa.gov/data/tcr/index.php?season=2019\&basin=atl. Atlantic TC track data (1980-2018) used in this study comes from a global tropical cyclone dataset which is archived by Massachusetts Institute Technology as a related resource of the open course "Tropical Meteorology", and located at $\mathrm{ftp}: / /$ texmex.mit.edu/pub/emanuel/HURR/tracks/. In this dataset, the Atlantic files were obtained from NOAA's Tropical Prediction Center. 
https://doi.org/10.5194/acp-2020-761

Preprint. Discussion started: 12 August 2020

(C) Author(s) 2020. CC BY 4.0 License.

\section{Author contributions}

$337 \quad \mathrm{ZZ}$ carried out the data analysis, led the interpretation of the results, and prepared the

338 manuscript with contributions from all co-authours. WZ contributed to the

339 interpretation of the results, provided extensive comments on manuscript, and secured

340 the funding.

341

342 Competing interests.

343 The authors declare that they have no conflict of interest.

344 
https://doi.org/10.5194/acp-2020-761

Preprint. Discussion started: 12 August 2020

(C) Author(s) 2020. CC BY 4.0 License.

345 Acknowledgments

346 This work is supported by National Natural Science Foundation of China Grants

347 (41675062, 41375096), and the Research Grants Council of the Hong Kong Special

348 Administrative Region, China (Projects No. CityU 11306417, 11335316).

349 


\section{References:}

Alpert, P., Y. J. Kaufman, Y. Shay-El, D. Tanre, and J. H. Joseph (1998), Quantification of dust-forced heating of the lower troposphere, Nature, 395, 367-370.

Bangert, M., A. Nenes, B. Vogel, H. Vogel, D. Barahona, V. A. Karydis, P. Kumar, C. Kottmeier, and U. Blahak (2012), Saharan dust event impacts on cloud formation and radiation over Western Europe, Atmos. Chem. Phys., 12, 4045-4063.

Bellouin, N., J. Quaas, J.-J. Morcrette, and O. Boucher (2013), Estimates of aerosol radiative forcing from the MACC reanalysis, Atmos. Chem. Phys., 13(4), 2045-2062.

Bian, H., and Coauthors (2013), Source attributions of pollution to the western Arctic during the NASA ARCTAS field campaign, Atmos. Chem. Phys., 13(9), 4707-4721.

Carlson, T. N., and S. G. Benjamin (1980), Radiative heating rates for Saharan dust, J. Atmos. Sci., $37,193-213$.

Cavazos, C., M. C. Todd, and K. Schepanski (2009), Numerical model simulation of the Saharan dust event of 6-11 March 2006 using the Regional Climate Model version 3 (RegCM3), J. Geophys. Res.-Atmos., 114, D12109, doi:10.1029/2008JD011078.

Chen, Y., S. M. Kreidenweis, L. M. Mclnnes, D. C. Rogers, and P. J. DeMott (1998), Single particle analyses of ice nucleating aerosols in the upper troposphere and lower stratosphere, Geophys. Res. Lett., 25, 1391-1394.

Chin, M., and Coauthors (2002), Tropospheric aerosol optical thickness from the GOCART model and comparisons with satellite and sun photometer measurements, J. Atmos. Sci., 59, $461-483$.

Colarco, P., A. da Silva, M. Chin, and T. Diehl (2010), Online simulations of global aerosol distributions in the NASA GEOS-4 model and comparisons to satellite and ground-based aerosol optical depth, J. Geophys. Res.-Atmos., 115(D14207), doi:10.1029/2009JD012820.

Cziczo, D. J., K. D. Froyd, C. Hoose, E. J. Jensen, M. Diao, M. A. Zondlo, J. B. Smith, C. H. Twohy, and D. M. Murphy (2013), Clarifying the dominant sources and mechanisms of cirrus cloud formation, Science, 340(6138), 1320-1324. 
Cziczo, D. J., D. M. Murphy, P. K. Hudson, and D. S. Thomson (2004), Single particle measurements of the chemical composition of cirrus ice residue during CRYSTAL-FACE, J. Geophys. Res., 109, D04201, doi:10.1029/2003JD004032.

DeMott, P. J., K. Sassen, M. Poellot, D. Baumgardner, D. Rogers, S. D. Brooks, A. J. Prenni, and S. M. Kreidenweis (2003), African dust aerosols as atmospheric ice nuclei, Geophys, Res. Lett., 30(14), doi:10.1029/2003GL017410.

Dunion, J. P., and C. S. Velden (2004), The impact of the Saharan air layer on Atlantic tropical cyclone activity, Bull. Am. Metorol. Soc., 85, 353-365.

Emanuel, K. A. (1986), An air-sea interaction theory for tropical cyclones. Part I: Steady-state maintenance, J. Atmos. Sci., 42, 1062-1071.

Emanuel, K. A. (1987), The dependence of hurricane intensity on climate, Nature, 326, 483-485.

Emanuel, K. A. (1995), Sensitivity of tropical cyclones to surface exchange coefficients and a revised steady-state model incorporating eye dynamics, J. Atmos. Sci., 52, 3969-3976.

Emanuel, K. A. (1999), Thermodynamic control of hurricane intensity, Nature, 401, 665-669.

Evan, A. T., J. Dunion, J. A. Foley, and A. K. Heidinger (2006), New evidence for a relationship between Atlantic tropical cyclone activity and African dust outbreaks, Geophys. Res. Lett., 33, 19813-19817.

Heidinger, A. K., M. J. Foster, A. Walther, and X. Zhao (2014), The Pathfinder Atmospheres-Extended AVHRR climate dataset, Bull. Am. Meteorol. Soc., 909-922, doi:10.1175/BAMS-D-12-00246.1.

Holben, B., and Coauthors (1998), AERONET-A federated instrument network and data archive for aerosol characterization, Remote. Sens. Environ., 66(1), 1-16.

Holland, G. J. (1997), The maximum potential intensity of tropical cyclones, J. Atmos. Sci., 54, $2519-2541$.

401 Hoose, C., and O. Mohler (2012), Heterogeneous ice nucleation on atmospheric aerosols: A 402 review of results from laboratory experiments, Atmos. Chem. Phys., 12(20), 9817-9854. 
Huang, J., B. Lin, P. Minnis, T. Wang, X. Wang, Y. Hu, Y. Yi, and J. K. Ayers (2006), Satellite-based assessment of possible dust aerosols semi-direct effect on cloud water path over East Asia, Geophys. Res. Lett., 33, L19802, doi:10.1029/2006GL026561.

Kahn, R. A., B. J. Gaitley, J. V. Martonchik, D. J. Diner, K. A. Crean, and B. Holben (2005), Multiangle Imaging Spectroradiometer (MISR) global aerosol optical depth validation based on 2 years of coincident Aerosol Robotic Network (AERONET) observations, J. Geophys. Res.-Atmos., 110(D10), doi:10.1029/2004JD004706.

Karyampudi, V. M., and T. N. Carlson (1988), Analysis and numerical simulations of the Saharan air layer and its effect on easterly wave disturbances, J. Atmos. Sci., 45, 3102-3136.

Karydis, V. A., P. Kumar, D. Barahona, I. N. Sokolik, and A. Nenes (2011), On the effect of dust particles on global cloud condensation nuclei and cloud droplet number, J. Geophys. Res., 116, D23204, doi:10.1029/2011JD016283.

Kaufman, Y. J., I. Koren, L. A. Remer, D. Tanre, P. Ginoux, and S. Fan (2005), Dust transport and deposition observed from the Terra-Moderate Resolution Imaging Spectroradiometer (MODIS) spacecraft over the Atlantic Ocean, J. Geophys. Res., 110, D10S12, doi:10.1029/2003JD004436.

Knutson, T. R., R. E. Tuleya, and Y. Kurihara (1998), Simulated increase of hurricane intensities in a $\mathrm{CO}_{2}$-warmed climate, Science, $279,1018-1020$.

Koehler, K. A., S. M. Kreidenweis, P. J. DeMott, M. D. Petters, A. J. Prenni, and C. M. Carrico (2009), Hygroscopicity and cloud droplet activation of mineral dust aerosol, Geophys. Res. Lett., 36, L08805, doi:10.1029/2009GL037348.

Lau, K. M., K. M. Kim, Y. C. Sud, and G. K. Walker (2009), A GCM study of the response of the atmospheric water cycle of West Africa and the Atlantic to Saharan dust radiative forcing, Ann. Geophys., 27(10), 4023-4037.

McCarty, W., L. Coy, R. Gelaro, A. Huang, D. Merkova, E. B. Smith, M. Sienkiewicz, and K. Wargan (2016), MERRA-2 input observations: Summary and Assessment. Technical Report Series on Global Modeling and Data Assimilation, NASA TM-2016-104606 46, NASA $\begin{array}{llll}\text { Global } \text { Modeling Assimilation Office. URL } & \end{array}$ https://gmao.gsfc.nasa.gov/reanalysis/MERRA-2/docs/. 
Nowottnick, E., P. Colarco, A. da Silva, D. Hlavka, and M. McGill (2011), The fate of the Saharan dust across the Atlantic and implications for a Central American dust barrier, Atmos. Chem. Phys., 11(16), 8415-8431.

Nowottnick, E., P. Colarco, R. Ferrare, G. Chen, S. Ismail, B. Anderson, and E. Browell (2010), Online simulations of mineral dust aerosol distributions: Comparisons to NAMMA observations and sensitivity to dust emission parameterization, J. Geophys. Res.-Atmos., 115(D3), doi:110.1029/2009JD012692.

Ramanathan, V., P. J. Crutzen, J. T. Kiehl, and D. Rosenfeld (2001), Aerosols, climate, and the hydrological cycle, Science, 294(5549), 2119-2124.

Reale, O., K. M. Lau, A. da Silva, and T. Matsui (2014), Impact of assimilated and interactive aerosol on tropical cyclogenesis, Geophys. Res. Lett., 41(9), 3282-3288.

Reichle, R. H., and Q. Liu (2014), Observation-corrected precipitation estimates in GEOS-5. Tech. Rep. 35, NASA Global Modeling and Assimilation Office. URL https://gmao.gsfc.nasa.gov/pubs/docs/Reichle734.pdf.

Rienecker, M. M., and Coauthers (2008), The GEOS-5 Data Assimilation System-Documentation of version 5.0.1, 5.1.0, and 5.2.0. Tech. Rep. 27, NASA Global Modeling and Assimilation Office. URL https://gmao.gsfc.nasa.gov/pubs/docs/Rienecker369.pdf.

Rienecker, M. M., and Coauthors (2011), MERRA: NASA's Modern-Era Retrospective analysis for Research and Applications. J. Clim., 24, 3624-3648.

Rotunno, R., and K. A. Emanuel (1987), An air-sea interaction theory for tropical cyclones. Part II: Evolutionary study using a nonhydrostatic axisymmetric numerical model, J. Atmos. Sci., 44, $542-561$.

Sassen, K. (2003), Saharan dust storms and indirect aerosol effects on clouds: CRYSTAL-FACE results, Geophys. Res. Lett., 30(12), doi:10.1029/2003GL017371.

Takacs, L. L., M. J. Suarez, and R. Todling (2015), Maintaining atmospheric mass and water balance within reanalysis. Technical Report Series on Global Modeling and Data Assimilation, NASA/TM-2014-104606 37, NASA Global Modeling and Assimilation Office. 
URL https://gmao.gsfc.nasa.gov/pubs/docs/Takacs737.pdf.

460

461

462

463

464

465

466

467

468

469

470

471

472

473

474

Wilcox, E. M., K. M. Lau, and K.-M. Kim (2010), A northward shift of the North Atlantic Ocean Intertropical Convergence Zone in response to summertime Saharan dust outbreaks, Geophys. Res. Lett., 37, L04804, doi: 10.1029/2009GL041774.

Wong, S., A. E. Dessler, N. H. Mahowald, P. Yang, and Q. Feng (2009), Maintenance of the lower tropospheric temperature inversion in the Saharan air layer by dust and dry anomaly, J. Clim., $22,5149-5162$.

Wu, L., S. A. Braun, J. J. Qu, and X. Hao (2006), Simulating the formation of hurricane Isabel (2003) with AIRS data, Geophys. Res. Lett., 33, 1029-1033.

Wu, L. (2007), Impact of Saharan air layer on hurricane peak intensity, Geophys. Res. Lett., 34, L09802, doi:10.1029/2007GL029564.

Zhu, A., V. Ramanathan, F. Li, and D. Kim (2007), Dust plumes over the Pacific, Indian, and Atlantic Oceans: Climatology and radiative impact, J. Geophys. Res., 112, D16208, doi: 10.1029/2007JD008427. 
https://doi.org/10.5194/acp-2020-761

Preprint. Discussion started: 12 August 2020

(c) Author(s) 2020. CC BY 4.0 License.

475 Table List:

476 Table 1. The climatology and anomalies of dust AOD averaged over the region of $10^{\circ}$

$477 \mathrm{~N}-25^{\circ} \mathrm{N}, 60^{\circ} \mathrm{W}-20^{\circ} \mathrm{W}$. For the extreme conditions, the magnitude of change

478 compared to the climatology is given along with the corresponding percentage.

\begin{tabular}{cccc}
\hline Month & $\begin{array}{c}\text { 40-yr average } \\
(1980-2019)\end{array}$ & $\begin{array}{c}\text { 8-yr strongest } \\
\text { condition }\end{array}$ & $\begin{array}{c}\text { 8-yr weakest } \\
\text { condition }\end{array}$ \\
\hline 6 & 0.174 & $+0.055(31.70 \%)$ & $-0.046(26.44 \%)$ \\
7 & 0.193 & $+0.046(23.78 \%)$ & $-0.048(24.87 \%)$ \\
8 & 0.149 & $+0.031(20.71 \%)$ & $-0.041(27.52 \%)$ \\
9 & 0.112 & $+0.036(31.83 \%)$ & $-0.037(33.04 \%)$ \\
\hline
\end{tabular}

479

480 Table 2. The climatology and anomalies of $\operatorname{SST}\left({ }^{\circ} \mathrm{C}\right)$ in extreme dust conditions over 481 the region of $10^{\circ} \mathrm{N}-25^{\circ} \mathrm{N}, 60^{\circ} \mathrm{W}-20^{\circ} \mathrm{W}$.

\begin{tabular}{cccc}
\hline Month & $\begin{array}{c}\text { 40-yr average } \\
(1980-2019)\end{array}$ & $\begin{array}{c}\text { 8-yr strongest } \\
\text { dust condition }\end{array}$ & $\begin{array}{c}\text { 8-yr weakest } \\
\text { dust condition }\end{array}$ \\
\hline 6 & 25.48 & $-0.31(1.22 \%)$ & $+0.01(0.04 \%)$ \\
7 & 26.10 & $-0.07(0.27 \%)$ & $-0.01(0.04 \%)$ \\
8 & 26.83 & $-0.10(0.37 \%)$ & $-0.09(0.34 \%)$ \\
9 & 27.31 & $-0.13(0.02 \%)$ & $+0.09(0.01 \%)$ \\
\hline
\end{tabular}


https://doi.org/10.5194/acp-2020-761

Preprint. Discussion started: 12 August 2020

(c) Author(s) 2020. CC BY 4.0 License.

Figure List:
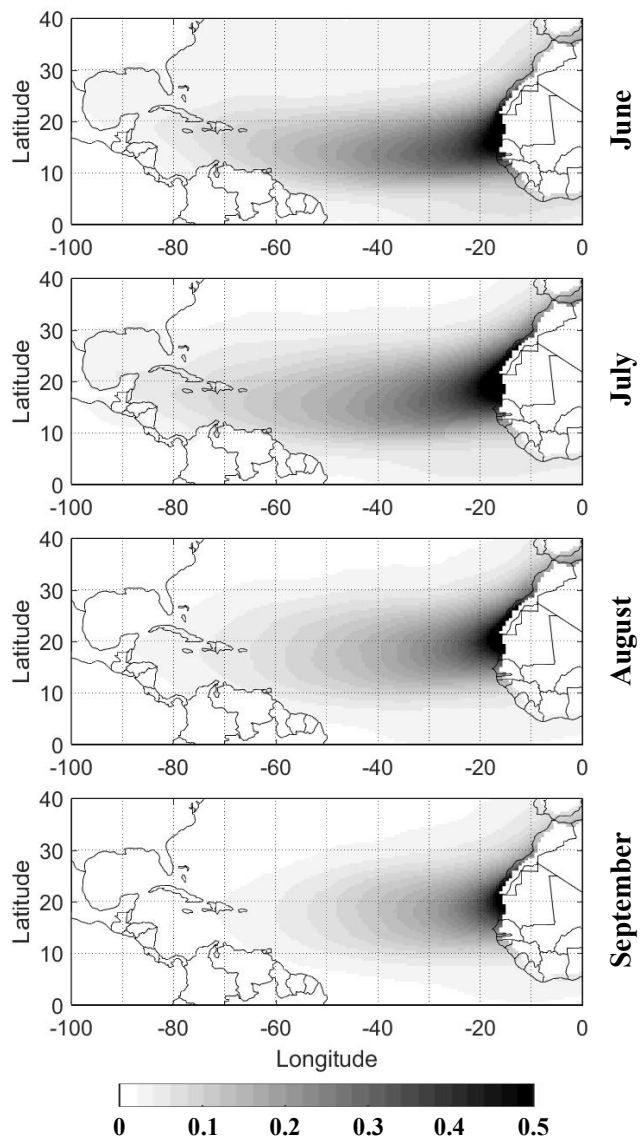

489 Figure 1. 40-yr average (1980-2019) of dust extinction AOD from the MERRA-2 reanalysis

490 product during summer.

491

492 
https://doi.org/10.5194/acp-2020-761

Preprint. Discussion started: 12 August 2020

(c) Author(s) 2020. CC BY 4.0 License.
Atmospheric

Chemistry

and Physics

Discussions
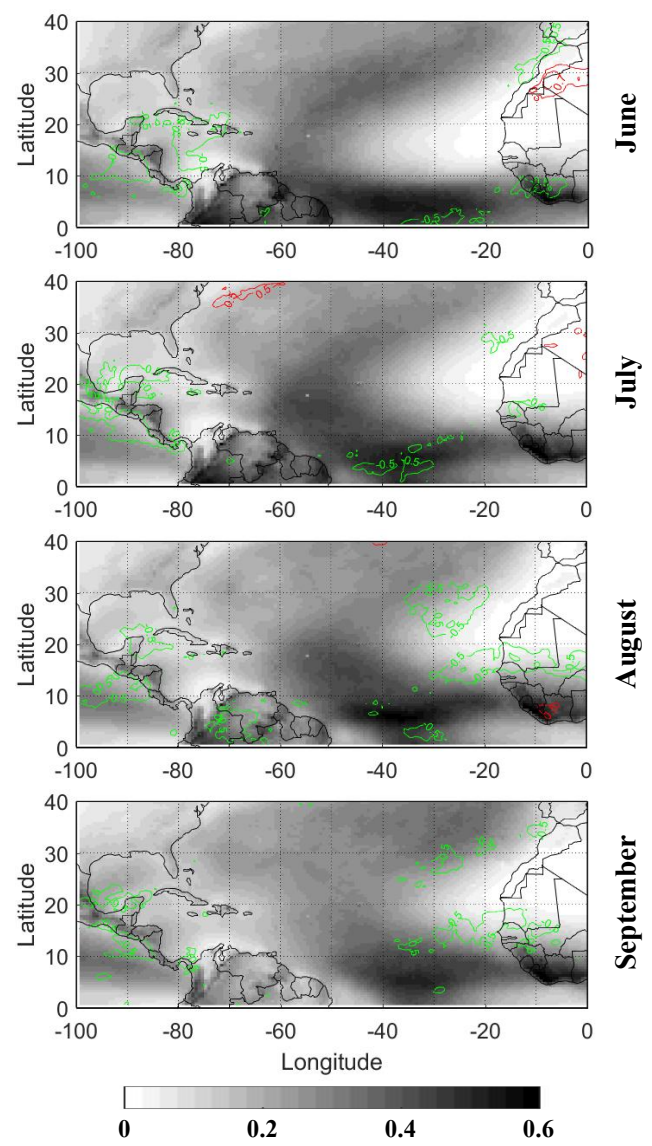

493 Figure 2. 40-yr average (1980-2019) of liquid water path (LWP; $\mathrm{kg} \mathrm{m}^{-2}$ ) from the MERRA-2

494 reanalysis product during summer. The green and red lines are the negative and positive

495 correlation coefficient contours, respectively, for the correlation between LWP and dust AOD at

496 each grid point.

497 

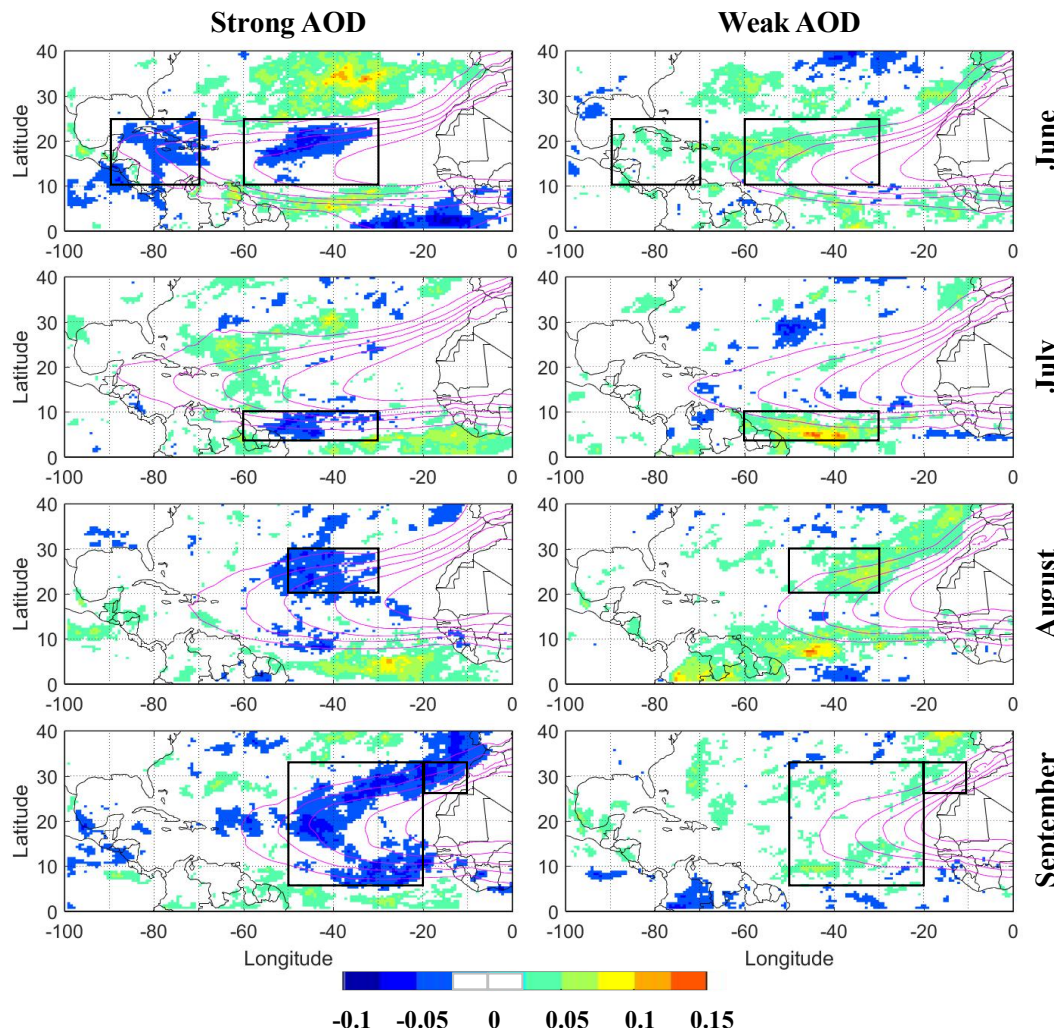

${ }_{\bar{C}}^{\circ}$

Figure 3. (Left column) The difference in LWP $\left(\mathrm{kg} \mathrm{m}^{-2}\right)$ between the 8 -yr strongest dust AOD $\left(10^{\circ} \mathrm{N}-25^{\circ} \mathrm{N}, 60^{\circ} \mathrm{W}-20^{\circ} \mathrm{W}\right)$ and the $40-\mathrm{yr}$ average, and (right column) the difference in LWP $\left(\mathrm{kg} \mathrm{m}^{-2}\right)$

500 between the 8-yr weakest dust AOD and the 40-yr average. Purple lines are the dust AOD contours of $0.06,0.1,0.14,0.2$, and 0.3 , averaged for the corresponding 8 years. The solid black outline shows the negative response region of LWP to dust. 
https://doi.org/10.5194/acp-2020-761

Preprint. Discussion started: 12 August 2020

(c) Author(s) 2020. CC BY 4.0 License.
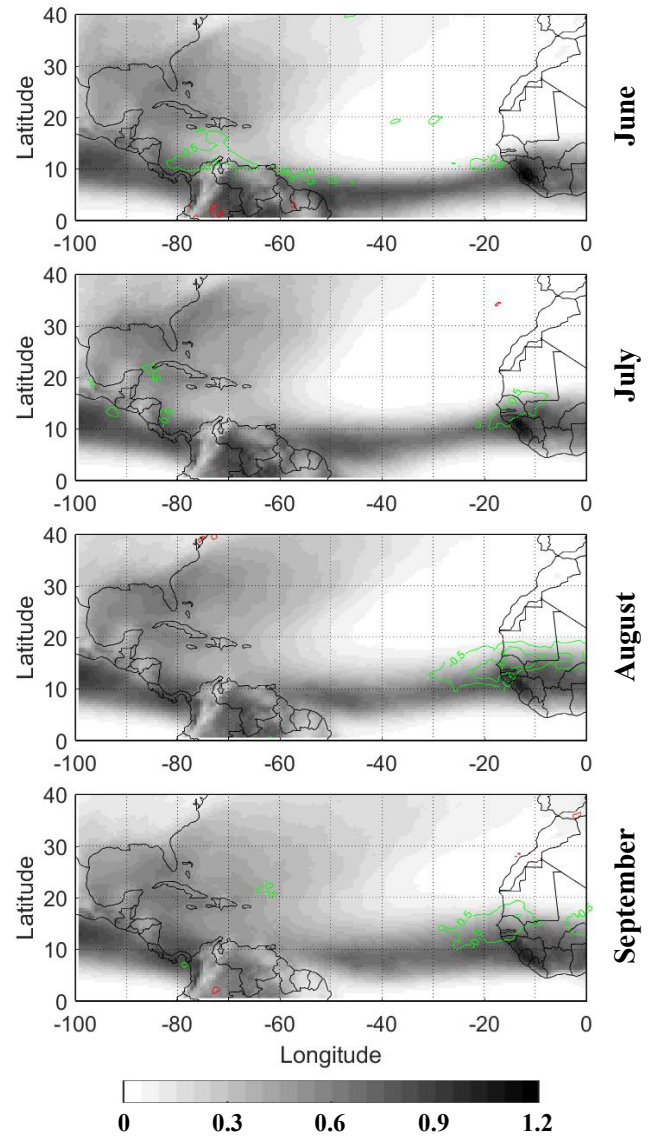

504 Figure 4. 40-yr (1980-2019) average of ice water path (IWP; $\mathrm{kg} \mathrm{m}^{-2}$ ) from the MERRA-2

505 reanalysis product during summer. The green and red lines are the negative and positive

506 correlation coefficient contours, respectively, for the correlation between IWP and dust AOD at 507 each grid point. 

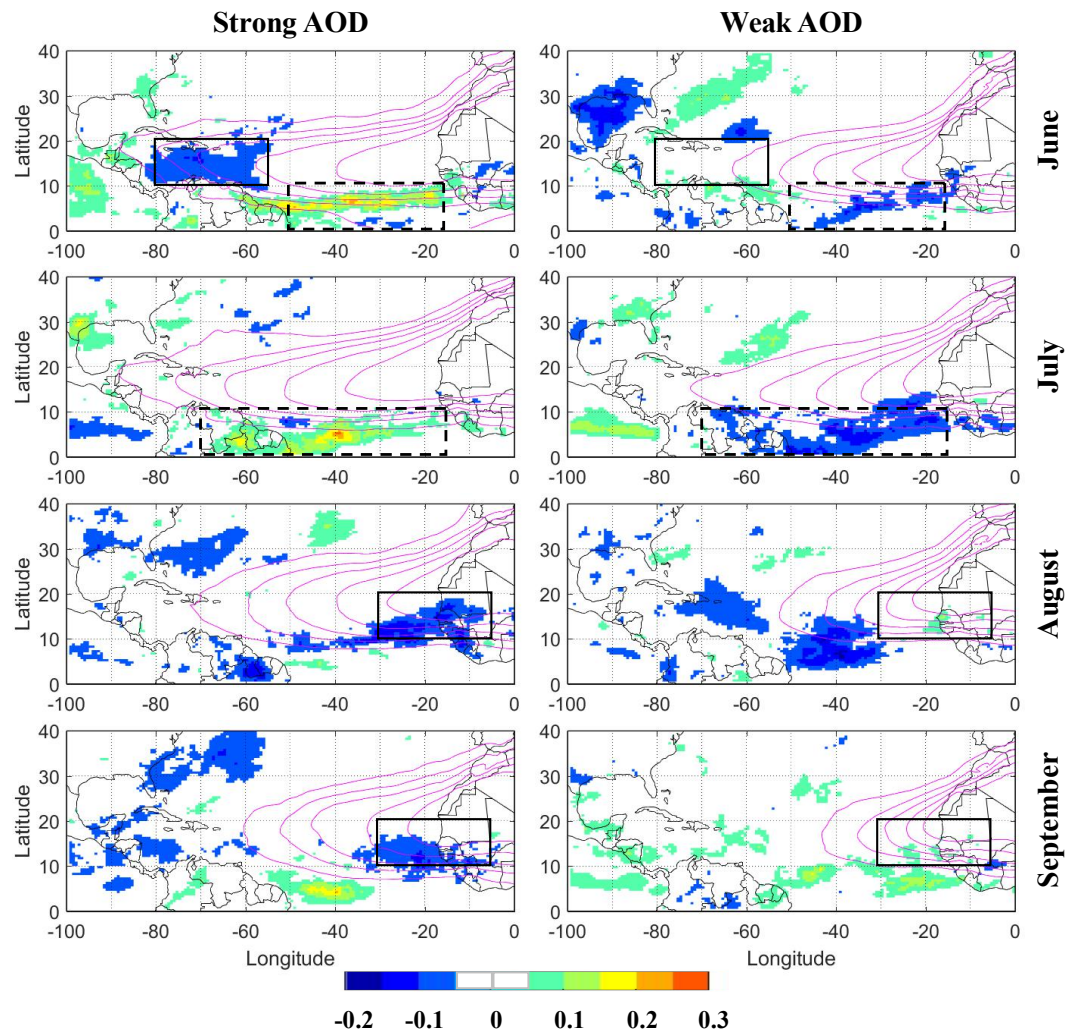

509 Figure 5. (Left column) The difference in IWP $\left(\mathrm{kg} \mathrm{m}^{-2}\right)$ between the 8 -yr strongest dust AOD $\left(10^{\circ} \mathrm{N}-25^{\circ} \mathrm{N}, 60^{\circ} \mathrm{W}-20^{\circ} \mathrm{W}\right)$ and the 40 -yr average, and (right column) the difference in IWP $\left(\mathrm{kg} \mathrm{m}^{-2}\right)$ between the 8-yr weakest dust AOD and the 40-yr average. Purple lines are the dust AOD contours of $0.06,0.1,0.14,0.2$, and 0.3 , averaged for the corresponding 8 years. The solid black outline shows the negative response region of IWP to dust, and the dashed black outline shows the positive response region of IWP to dust. 
https://doi.org/10.5194/acp-2020-761

Preprint. Discussion started: 12 August 2020

(c) Author(s) 2020. CC BY 4.0 License.
Atmospheric 을

Chemistry

and Physics

Discussions
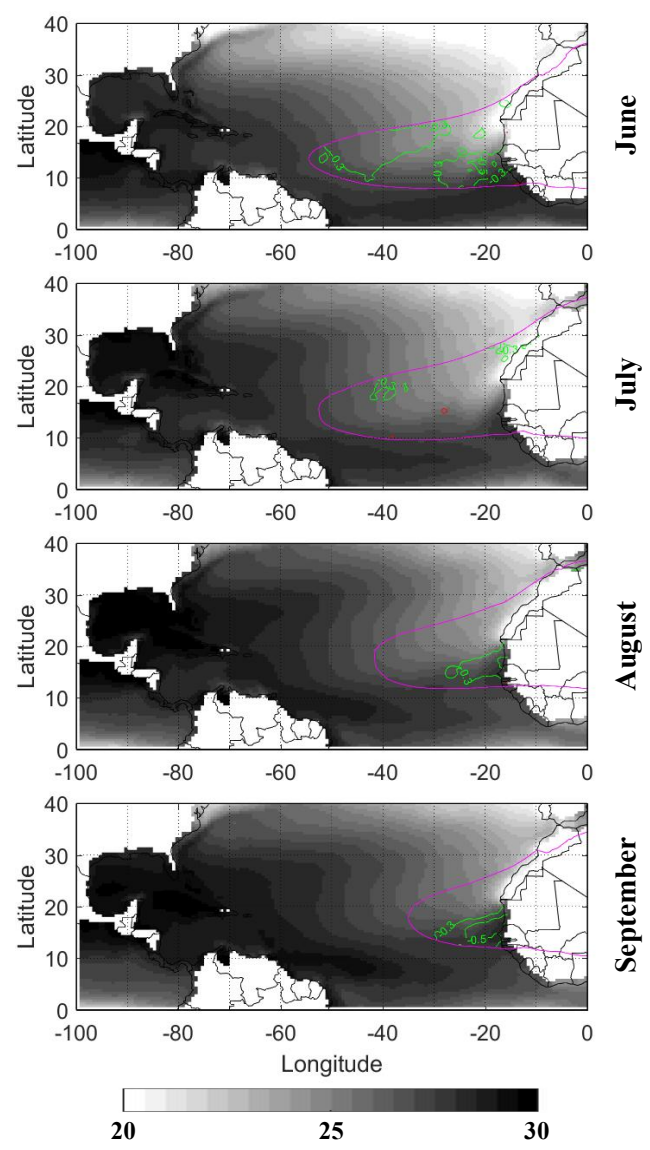

516 Figure 6. 40-yr (1980-2019) average of SST $\left({ }^{\circ} \mathrm{C}\right)$ from the MERRA-2 reanalysis product during

517 summer. The green and red lines are the negative and positive correlation coefficient contours for

518 the correlation between SST and dust AOD at each grid point. Purple lines are the 40-yr

519 (1980-2019) averaged dust AOD contour of 0.15. 

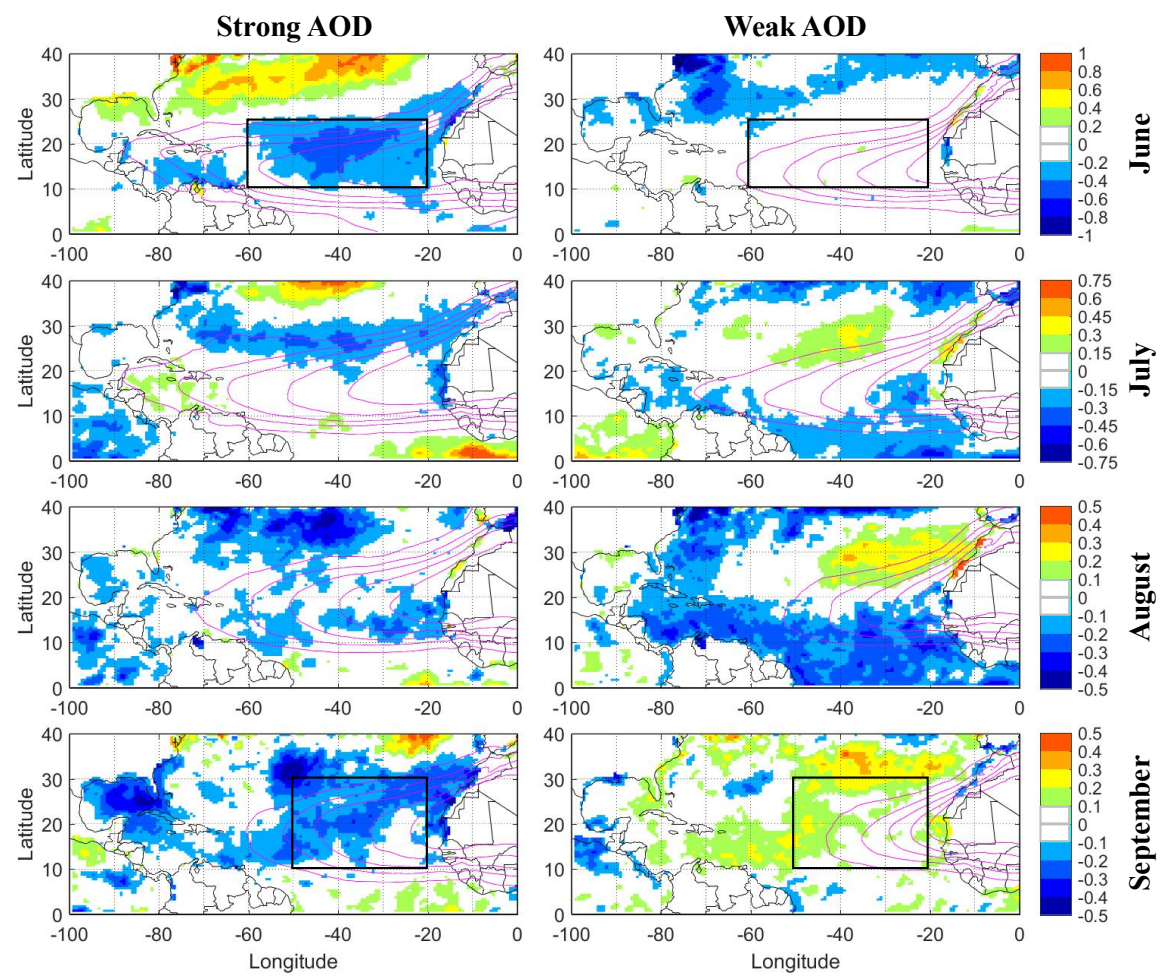

Figure 7. (Left column) The difference in SST $\left({ }^{\circ} \mathrm{C}\right)$ between the 8 -yr strongest dust AOD

$\left(10^{\circ} \mathrm{N}-25^{\circ} \mathrm{N}, 60^{\circ} \mathrm{W}-20^{\circ} \mathrm{W}\right)$ and the 40 -yr average, and (right column) the difference in SST $\left({ }^{\circ} \mathrm{C}\right)$ 
https://doi.org/10.5194/acp-2020-761

Preprint. Discussion started: 12 August 2020

(c) Author(s) 2020. CC BY 4.0 License.
Atmospheric

Chemistry

and Physics

Discussions
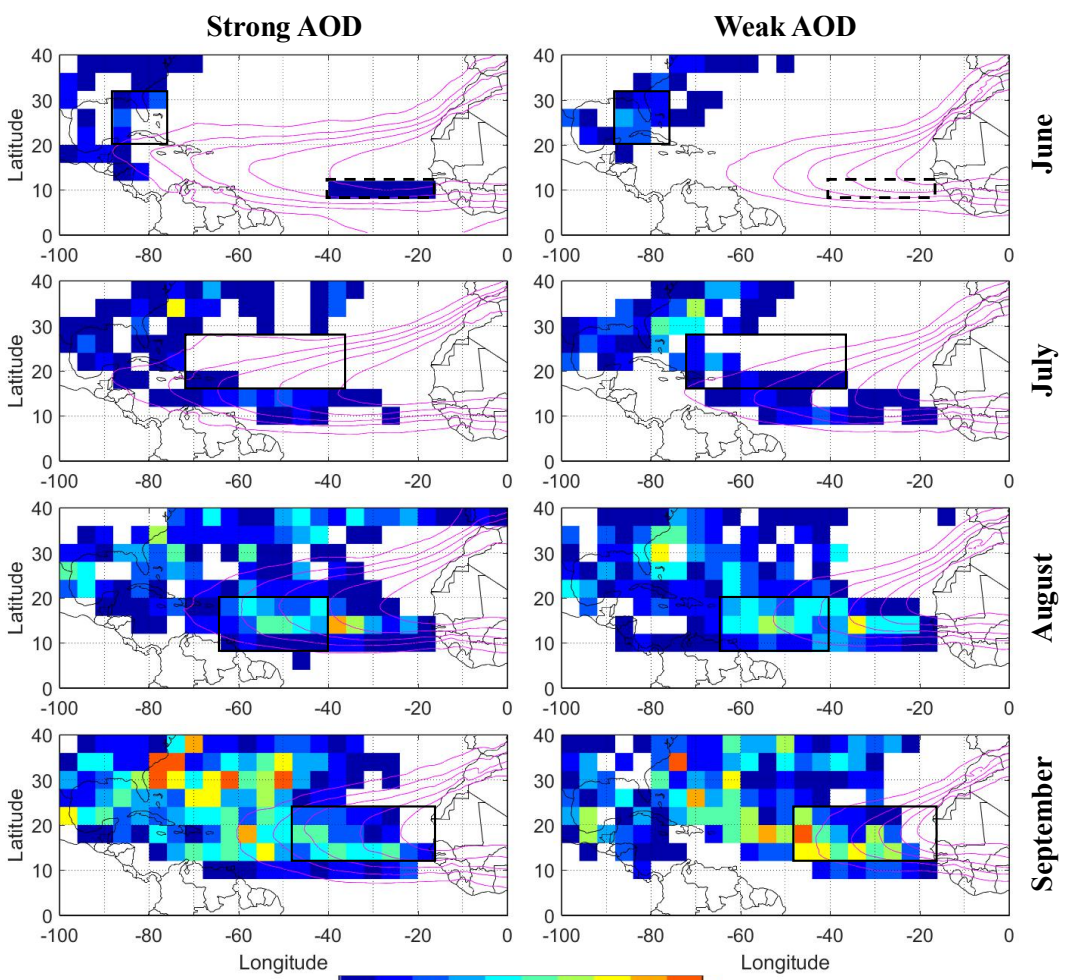

$\sum_{0}^{00}$

$\begin{array}{llllll}0 & 0.2 & 0.4 & 0.6 & 0.8 & 1\end{array}$

Figure 8. Comparison of TC days at 4-degree grid resolution between the 8-yr strongest and weakest dust conditions. The images represent annual average values. Purple lines are the dust AOD contours of $0.06,0.1,0.14,0.2$, and 0.3 , averaged for the corresponding 8 years. The solid black outline shows the negative response region of TC days to dust, and the dashed black outline shows the positive response region of TC days to dust. 
https://doi.org/10.5194/acp-2020-761

Preprint. Discussion started: 12 August 2020

(c) Author(s) 2020. CC BY 4.0 License.

(ब) (1)
Atmospheric

Chemistry

and Physics

Discussions
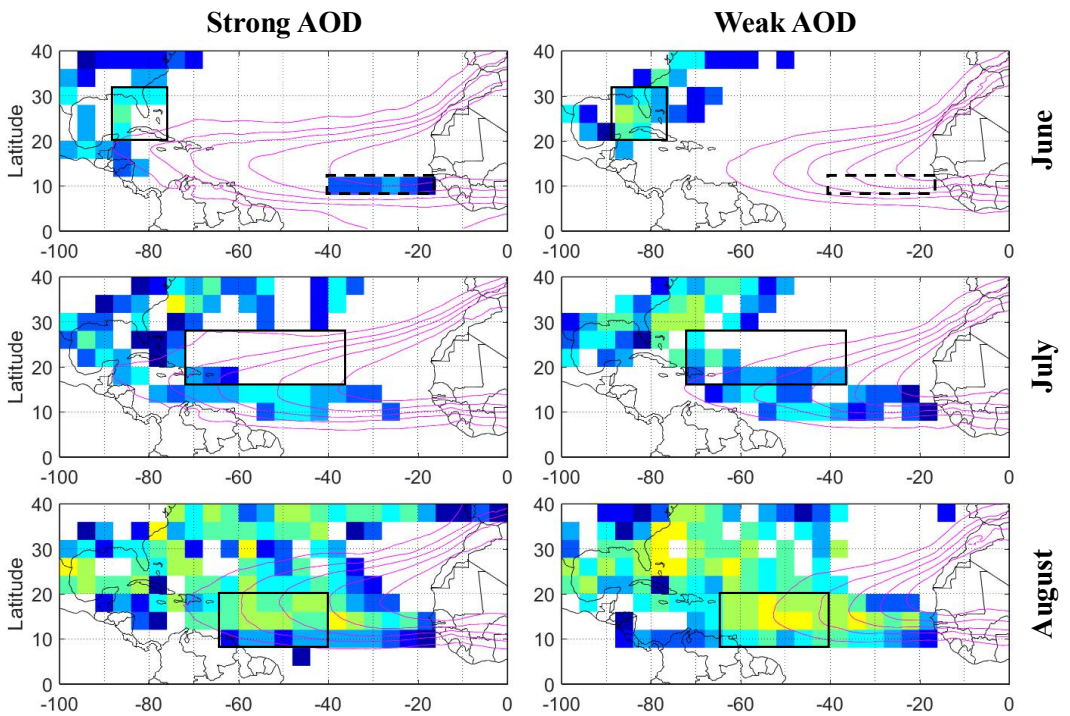

氙
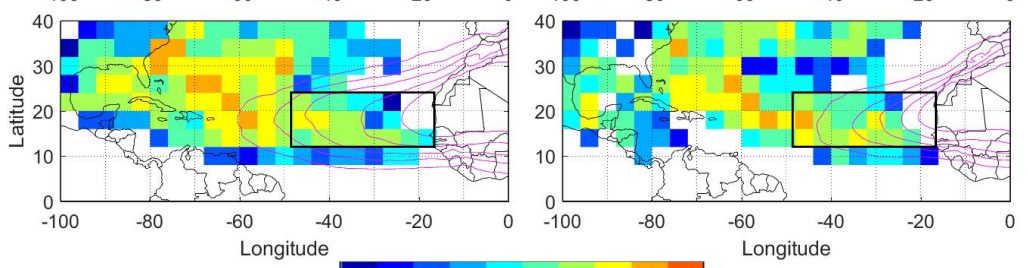

हัँّ

$\begin{array}{llllll}0 & 10^{0.5} & 10^{1} & 10^{1.5} & 10^{2} & 10^{2.5}\end{array}$

Figure 9. Same as Figure 8, but for TC intensity $\left(\mathrm{m} \mathrm{s}^{-1}\right)$. 

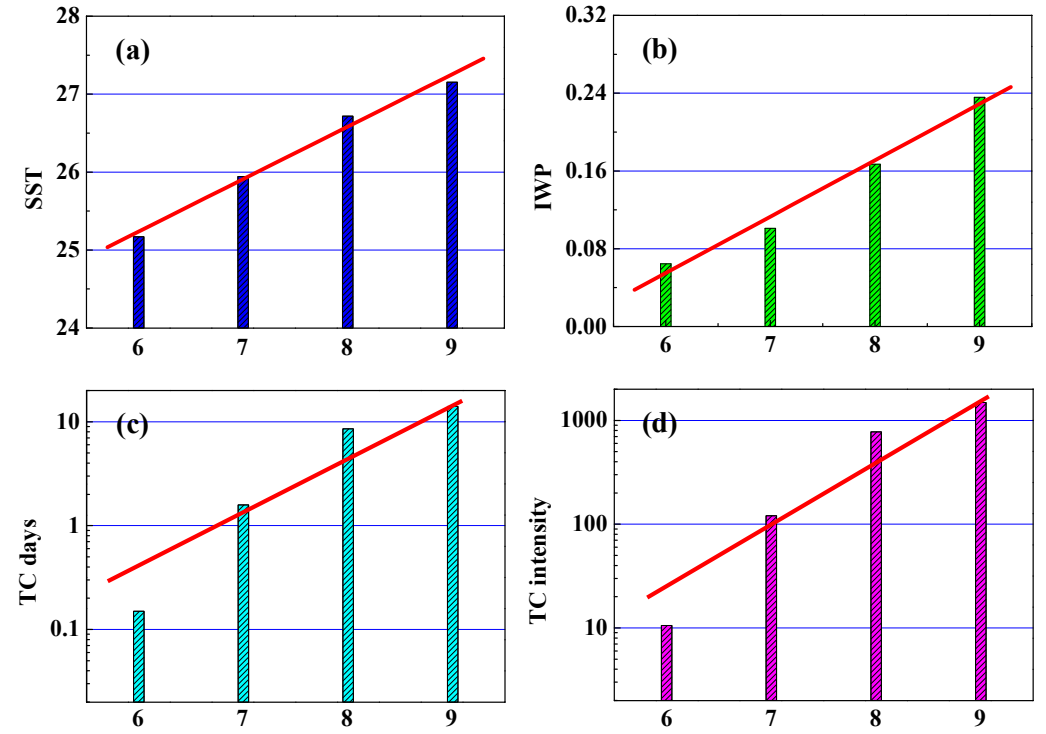

535 Figure 10. Monthly variation (from June to September) of (a) SST $\left({ }^{\circ} \mathrm{C}\right)$, (b) IWP $\left(\mathrm{kg} \mathrm{m}^{-2}\right)$, (c) TC

536

537

538

539

540

541

542

days, and (d) TC intensity $\left(\mathrm{m} \mathrm{s}^{-1}\right)$ over the region of $20^{\circ} \mathrm{W}-60^{\circ} \mathrm{W}, 10^{\circ} \mathrm{N}-30^{\circ} \mathrm{N}$, averaged during the 40-yr period (1980-2019). The red boldface lines in the SST and IWP panels indicate the least-squares best fit line to the data, and the linear increase tendency in the data. The red boldface lines in the TC days and intensity panels have the same linear increase tendency as SST. 